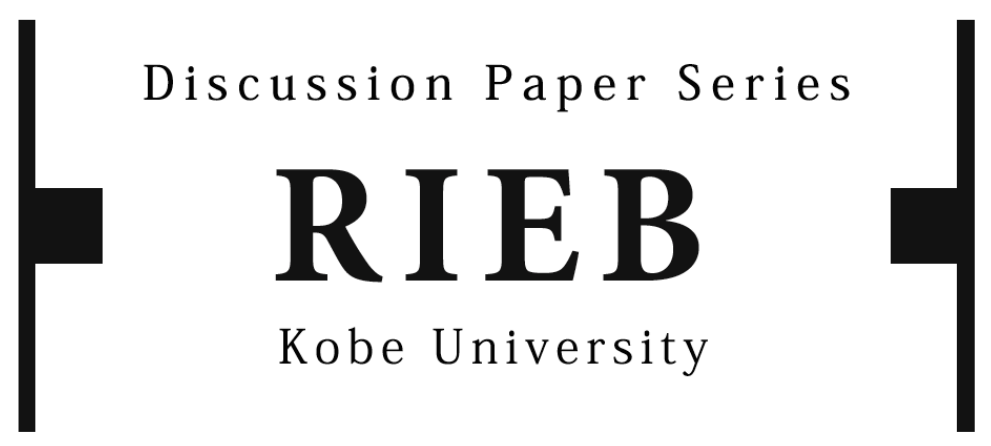

DP2013-05

\title{
Recent Changes in Micro-Level Determinants of Fertility in India: Evidence from National Family Health Survey Data*
}

\author{
Katsushi S. IMAI \\ Takahiro SATO
}

February 18, 2013

* The Discussion Papers are a series of research papers in their draft form, circulated to encourage discussion and comment. Citation and use of such a paper should take account of its provisional character. In some cases, a written consent of the author may be required.

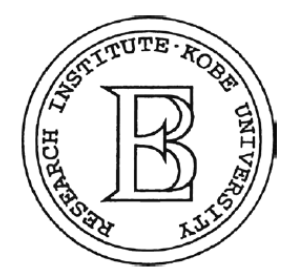

Research Institute for Economics and Business Administration Kobe University 


\title{
Recent Changes in Micro-Level Determinants of Fertility in India: Evidence from National Family Health Survey Data
}

\author{
31 January 2013
}

\author{
Katsushi S. Imai \\ Economics, School of Social Sciences, University of Manchester, UK \\ $\boldsymbol{\&}$
}

Takahiro Sato

Research Institute for Economics \& Business Administration (RIEB), Kobe University, Japan

Corresponding Author:

Dr. Katsushi. S. Imai

Economics, School of Social Sciences, University of Manchester, Arthur Lewis Building, Oxford Road, Manchester M13 9PL, UK, Telephone:+44-(0)161-275-4827, Fax:+44-(0)161-275-4812, Email: Katsushi.Imai@ manchester.ac.uk

\section{Acknowledgements:}

We are grateful to the financial support of Grant-in-Aid for Scientific Research (S) (\#21221010), the Australian Research Council-AusAID Linkage grant LP0775444 in Australia, and the small grant from DFID and Chronic Poverty Research Centre at the University of Manchester in the UK. Research support from RIEB, Kobe University for the first author is greatly acknowledged. We have benefited from valuable comments at various stages from Barrientos Armando, Sonia Bhalotra, Pranab Bardhan, Per Eklund, Raghav Gaiha, Raghbendra Jha, Kunal Sen, Shoji Nishijima, Yoshifumi Usami, Koji Yamazaki and participants in seminars at Harvard, Manchester, Bristol, Kobe, Osaka City and Doshisha Universities and the international conference on 'New Directions in Welfare' at St Catherine's College, Oxford University, 29 June - 1 July 2009 and the joint Kobe-Hanyang Workshop at RIEB, Kobe University on $28^{\text {th }}$ May 2010. Valuable comments from two referees are greatly acknowledged. The views expressed are, however, those of the authors' and do not necessarily represent those of the organisations to which they are affiliated. 


\title{
Recent Changes in Micro-Level Determinants of Fertility in India: Evidence from National Family Health Survey Data
}

\begin{abstract}
This paper empirically investigates the determinants of fertility and their changes in recent years drawing upon large household data sets in India, namely National Family Health Survey (NFHS) data over the period 19922006. It is found that there is a negative and significant association between the number of children and parental education when we apply OLS, ordered logit and pseudo panel models, while in case of IV model only mother's literacy is negatively associated with the number of children. It is implied by the results of OLS and ordered logit models that households belonging to Scheduled Castes (SCs) tend to have more children than the rest. Our results suggest that policies of national and state governments to support social infrastructure, such as school at various levels and to promote both male and female education, particularly for households belonging to SCs, would be very important to reduce fertility and to speed down the population growth.
\end{abstract}

Key Words: Fertility, Parental Education, Scheduled Caste, Social Backwardness, NFHS (National Family Health Survey), India, Asia

\section{Introduction}

The population problem is still one of the important global issues in the $21^{\text {st }}$ century in light of alleviating world poverty and guaranteeing food security. The population increase is also closely related to global warming simply because more people will consume more resources. ${ }^{1}$ 
Based on the UN estimate in 2012, the world population is estimated to reach 6.90 billion by the end of 2010 and 9.31 billion in 2050 (Table 1). More than one third of the current world population is concentrated in India and China. However, India is likely to be the most populous country in the world by 2050, while China's population will be reduced to 1.30 billion under certain assumptions on mortality and fertility changes (the United Nations, 2012). While curbing the population growth in SubSaharan African (SSA) countries will undoubtedly remain crucial in providing a solution for the global population problem, India's population problem, however, would be equally important, at least in terms of its size.

(Table 1 to be inserted)

The population problem is one of the crucial domestic issues for India as well because, for example, the fertility decline will have direct and indirect impacts on national poverty. ${ }^{2}$ If the calculation of the poverty rate is based on per capita expenditure or income, the reduction in fertility will decrease it significantly. If the household has fewer children, then the access to education or health services for each child will be increased, which would improve the poverty situations indirectly. Economic growth is influenced by population growth and fertility changes, while the former would affect the latter in a complex way, for example, through technical changes (e.g. Rosenzweig, 1990).

Although India was among the first developing countries to implement family planning programs, authoritarian birth control measures corresponding to China's 'one child policy' have never been included as a policy option except for a very short period during the mid 1970's. While the population trend has been upwards since the last century, it is conjectured that India is now moving from the second stage to the 
third stage of the demographic transition. ${ }^{3}$ Indeed, the annual growth rate of the population went down from $2.3 \%$ in $1960-1970$ to $1.7 \%$ in $1995-2000$ (Mahbub ul Haq Human Development Center 2002). Few studies, however, have examined the causes for this structural change using the household or individual survey data.

The objective of the present study is to identify the determinants of fertility rates in India and their changes drawing upon National Family Health Survey (NFHS) Data in 1992-3, 1998-9 and 2005-6, given the possible changes in fertility behavior in this period with high economic growth rate and increased education opportunities. ${ }^{4} \mathrm{An}$ individual household's fertility decision which underlies macro-level demographic transition can be directly analysed by using the household data sets. As one of our main focuses, we will examine the role of parental education in reducing the fertility rates. The role of female education in fertility reduction in India has been reported, for example, by Subbarao and Raney (1995) and Drèze and Sen (2002), but the present study highlights both female and male education. The impacts of other household socioeconomic characteristics on fertility are also tested.

The form of the data (e.g. cross section or panel data) or their level of aggregation (e.g. national, state, district, or household level) varies considerably among different studies to draw these conclusions. For example, Subbarao and Raney (1995) and Drèze and Murthi (2001) used the district-level data, the data which aggregate the census data at district levels in India. However, few studies have examined the determinants of fertility using household level data despite the fact that fertility decision is actually made at individual or household levels. Drèze and Murthi (2001, p.40) recognize the value of employing household-level data as follows: “...if fertility decisions are, in fact, driven mainly by individual and household characteristics (with social effects playing little role), then household-level analyses are more appropriate, 
bearing in mind the potential aggregation problems involved in treating the district as the unit of analysis." The present study attempts to fill the gap.

The rest of the paper is organized as follows. An analytical framework is outlined in Section 2 to motivate our empirical study. The data we use in this paper are described with their basic statistical analysis in Section 3. After the presentation of econometric models in Section 4, we report and discuss the regression results in Section 5. The final section offers concluding remarks with some policy implications.

\section{Analytical Framework}

This section outlines a basic analytical framework with focus on the factors which would influence the number of children a household wishes to bear. The neoclassical approach to understanding a household's fertility decision is based on its utility maximization behavior, which is subject to budget constraints (e.g. Becker 1960, 1981; Becker and Lewis, 1973; Bardhan and Udry 1999). While it is possible to use the framework of 'unitary' model (e.g. Becker, 1981; Becker and Lewis, 1973) which focuses on the trade-off between the number of children and the current consumption of goods, our presentation below is based on a version of the 'collective' model of household behavior that explicitly models intra-household resource allocation (e.g. Browning and Chiappori 1998) because the collective model explicitly analyses the bargaining relationship between mother and father as a main determinant of the fertility outcome.

We consider a two-person household with a wife (or a mother, $m$ ) and a husband (or a father, $f$ ). Let $x_{i}$ be the $i^{\text {th }}$ person's consumption $(i=m, f)$, and $n$ be the number of children. The $i^{\text {th }}$ person's utility is $U_{i}\left(x_{i}, n ; A_{i}\right)$ where $A_{i}$ is a vector consisting of exogenous factors that determine the preferences of the individual $i$. In this setting, the 
household utility function is defined as $\gamma U_{m}+(1-\gamma) U_{f}$ where $\gamma$ represents the "bargaining power" of a mother $(m)$ in a household $(0<\gamma<1)$. The household's utility maximization problem is specified as follows:

$\operatorname{Max} U=\gamma U_{m}\left(x_{m}, n ; A_{m}\right)+(1-\gamma) U_{f}\left(x_{f}, n ; A_{f}\right)$

subject to

$$
I=p_{m} x_{m}+p_{f} x_{f}+p_{c} n
$$

where $I$ is a household's income, $p_{i}$ is the price of the private goods for mother $(m)$ or father $(f)$, and $p_{c}$ is the price of public goods, that is, children in a sense that spending in children is common for both mother $(m)$ and father $(f)$. In general, the optimal $n^{*}$ will depend on parameters such as $\gamma, p_{c}, I, p_{i}$, and $A_{i}$ as in the following reduced form equation of the collective model:

$n^{*}=n^{*}\left(\gamma, I_{,}, p_{m}, p_{f}, p_{c}, A_{m}, A_{f}\right)$

This model sheds light on a few important aspects of the household fertility decision which underlies demographic transition at macro level. For example, "bargaining power" $\gamma$ may reflect "women's agency" which can be defined as "an individual's (or group's) ability to make effective choices and to transform those choices (where) "agency" can be understood as the process through which women and men use their endowments and take advantage of economic opportunities to achieve desired outcomes" (World Bank, 2012, p.150). Drèze and Sen (2002, Chapter 7) argue that "women's agency" is influenced by female education as well as their ability to earn an independent income through paid employment and it improves the quality of life of women relative to that of men. However, because the NFHS data do not have any employment data, we only consider the general effect of female education on women's bargaining power. This effect is considered to be positive as better educated women can make more effective choices as an agent than less educated women. 
It is further assumed here that the stronger bargaining power of mother $(m)$ over father $(f)$ reflected in higher $\gamma$ generally leads to fewer children, given that mother is less likely than father, to value $n$, the number of children due to her health risk for child bearing and/or her heavier load of household tasks imposed on her in raising children in the future. A higher relative bargaining power of women over men may thus lead women to have a larger influence on family planning. ${ }^{5}$ In this framework, a higher level of female education is likely to reduce the number of children through the higher bargaining power of mother, $\gamma$. That is, education will increase women's bargaining power, $\gamma$ (or women's agency), which in turn will reduce $n^{*}$, the optimal number of children. ${ }^{6}$

Furthermore, the preferences $A_{i}$ represent each household member's attitude toward the fertility decision, which may be different in various classes, social groups, religious communities, and regions, and they may move toward "small family value" with social and economic changes. ${ }^{7}$ Economic growth increases a household's income level $I$ with a consequent effect on consumption $x_{i}$, and the number of children $n^{*}$. Implicit in the model is that an increase in the income level lowers $n$ and increases $x_{i}{ }^{8}$

In addition, as women attend schools and participate in labour markets more than they did previously and as the wages increase, the opportunity cost of raising children $p_{c}$ will increase. As a consequence of the substitution effect, a household may reduce its $n^{*}$. This also predicts the negative relation between female education and the number of children, which will be tested in subsequent sections.

In sum, the above simplified version of the collective household model implies that (i) the higher bargaining power of mother $(\mathrm{m}), \gamma$, decreases $n^{*}$, an optimal number of children; (ii) education of mother decreases $n^{*}$ through the increased bargaining power of mother, $\gamma$ (as an implication derived by (i)); (iii) a household's income level $I$ 
decreases $n^{*}$; (iv) the preferences $A_{i}$ (e.g. social groups, religious communities, and regions) influence $n^{*}$; and (v) the higher $p_{c}$ (e.g. through a higher opportunity cost of raising children due to higher female wages) reduces $n^{*}$, an optimal number of children. That is, social, household and individual characteristics will influence the household decision between mother and father regarding the optimal number of children a mother a woman will bear. We cannot test all the predictions or implications of the model due to data constraints, but we will highlight some of these in the subsequent sections.

\section{Data}

This study draws upon NFHS Data in 1992-3, 1998-9 and 2005-6 (or NFHS-1, NFHS-2 and NFHS-3). The NFHS is a major nationwide, large multi-round survey conducted in a representative sample of households in India with focus on health and nutrition of household members, especially of women and young children. ${ }^{9}$ The survey also contains the detailed data on fertility and mortality. A direct proxy for the fertility rate is available from NFHS, which has a question to ask mothers aged 15- 49 years old on how many children they have borne, after excluding any miscarriage but including any death of children. We used the number of children based on this question as a dependent variable.

Table 2 summarizes the recent trend of total fertility rate (TFR) ${ }^{10}$ by region in India. Overall, TFR declined from 1992 to 2005 across different areas and regions in India. However, there remains a significant disparity between rural and urban areas. Also noted is a disparity among different regions, reflecting disparity among different states. TFRs are much lower in South (Andhra Pradesh, Karnataka, Kerala and Tamil Nadu) and West (Goa, Gujarat and Maharashtra) than in Central (Madhya Pradesh 
and Uttar Pradesh), East (Bihar, Orissa and West Bengal) or Northeast (Arunachal Pradesh, Assam, Manipur, Meghalaya, Mizoram, Nagaland, Sikkim and Tripura). North is roughly at the national average, while TFR is varied within North raging from 1.94 in Himachal Pradesh and 1.99 in Punjab to 3.21 in Rajasthan in 2005.

(Table 2 to be inserted)

\section{Econometric Models}

The main objective of our econometric models is to identify the key determinants of fertility proxied by the number of children. The basic idea of specifying the econometric model of fertility behavior draws upon Drèze and Sen (2001).

\section{(1) OLS Model}

Using the cross sectional household data constructed by three rounds of NFHS, we estimate the reduced form equation by OLS as a baseline model. ${ }^{11}$

$$
n_{i}=n_{i}\left(E_{i}^{m}, E_{i}^{f}, A_{i}^{m}, B_{i}, O_{i}, M_{i}, L_{i}, S_{i}, R, D\right)
$$

$i$ denotes household and the dependent variable is $n_{i}$ the number of children a mother has borne. $n_{i}$ is estimated by the following explanatory variables.

$E_{i}^{m}:$ A vector of the mother's education (Case (A): whether literate or not; Case (B): a set of dummy variables on the level of educational achievement of mother). In Case (A), education is simply defined in terms of literacy of a mother, with focus on the effect of being illiterate on fertility. In Case (B), we used a set of dummies, namely, (i) whether attended or completed primary school, (ii) whether completed secondary school, and (iii) whether completed higher education. Each dummy variable takes either 1 or 0 . 
In general, female education can be considered to be a proxy for the opportunity cost of raising children. The forgone income by, for example, leaving a job or shifting from a full-time to a part-time job for childcare after giving birth may be larger for the women who are more educated and tend to have the job with higher income. Furthermore, an increase in female education will empower women and their increased bargaining capability in households would enable them to control over the fertility in India (Drèze and Murthi, 2001). Using the NFHS-2 and 3 data on Andhra Pradesh, Sujatha and Reddy (2009) have shown that women's autonomy in decision making, access to money and freedom of movement increase with education and reduces fertility. Moreover, educated women may be able to understand 'the quality' of children better and thus they may place more importance on 'quality' over 'quantity', which would reduce their desired number of children.

It is often argued that educated women also tend to have more knowledge of contraception than illiterate women which will lead to the smaller number of children, but the effect of education has to be understood in the context of family planning programmes. When a central or state government provides the family planning services to women, they tend to be availed only by educated women who are openminded and can understand the logic of family planning, and less educated women groups generally large in size remain untouched (Singh, 2001). This would make the negative relation between education and fertility even further pronounced.

Higher education also makes women delay the age of marriage or of giving birth to the first child. This results in the negative relationship between women's education and the number of children particularly in case of OLS where the women in all the age groups (15-49 years old) are pooled. ${ }^{13}$ Educated women with higher income 
would place more importance on 'quality' of children over 'quantity' and this would make the fertility-education correlation further negative.

$E_{i}^{f}:$ A vector of the father's education (defined same as above).

Higher level of the father's education might lead him to cooperate with mother in developing the family plan and using contraceptives. This has been relatively neglected in the literature with a few exceptions, such as, Bhat (2002). However, because in many households men tend to spend much less time for childcare than women, the negative link between education and fertility is expected to be weaker. However, educated men who tend to be open-minded would be willing to listen to women's needs (e.g. preference for children's 'quality') and to cooperate with women for family planning. An expected sign of the coefficient estimate is thus negative.

$A_{i}^{m}:$ Mother's age and its square, which take account of the life cycle effect of mother. $B_{i}$ : Social backwardness of the household in terms of (i) whether a household belongs to Scheduled Caste and (ii) whether it belongs to scheduled tribe.

$O_{i}$ : Occupation of parents in terms of (i) whether the household is classified as nonagricultural self-employment and (ii) whether as agricultural self-employment. We assume that self-employment households have a greater demand for child labour and thus higher fertility. This is a permanent occupation category and not affected by unemployment.

$M_{i}$ : Religion of the household. We use the Muslim dummy only in consideration of the unique fertility behavior among Muslims. Fertility rates are supposed to be high among Muslims because of their pronatalist ideology and opposition to family planning or early marriages (e.g. Mouhasha and Rama Rao, 1999, Mishra, 2004, Bhat and Zavier, 2005). 
$L_{i}$ : Owned land as a measure of wealth (1/1000 hectare). ${ }^{14}$

$S_{i}$ : Son-preference index is the dummy variable on son-preference based on the survey question asking a mother about her preferred numbers of sons and/or daughters: 'How many of these children would you like to be boys and how many would you like to be girls?' This dummy variable takes 1 if the number of boys demanded by a mother is larger than that of girls. In India, the fact that sons are preferred over daughters is well known and thus the expected sign of this index is positive. Two other interpretations can be made of this index. First, it reflects higher expected wages of sons and higher expected expenses related to daughters (e.g. dowry), leading to higher expected household net income in the future by having more sons. Second, the index may be correlated with the opportunity cost of raising children, since young girls, whose opportunity costs are negligible, are usually involved in raising younger brothers and sisters.

$R:$ The degree of urbanisation proxied by the rural sector dummy (whether in rural areas).

$D:$ A vector of state dummy variables.

\section{(2)Ordered Logit Model}

As the dependent variable is discrete and ordinal with its range confined to small numbers $(0,1,2,3, \ldots)$, we also estimate the ordered logit model as a robustness check. ${ }^{15}$ The same set of explanatory variables for OLS is used for ordered logit model. As we will see later, the results of ordered logit are very similar to those derived by OLS.

\section{(3)Instrumental Variable Model}


For most of parents in India, the period for fertility starts after education is completed. However, some young women give birth when they are in their late teens and for them the decision on whether they should take secondary/higher education or marry and give birth may be made simultaneously where 'fertility' may affect 'female education' (i.e. the opposite direction of causality). Though the proportion of those women is not likely to be so large ${ }^{16}$, this may cause the correlation of education and the error term, which will bias the coefficient estimate. Instrumental Variable (IV) model, such as 2SLS, would partially address this issue. As a robustness check for OLS, we estimate the IV model (Case (C)) where mother's literacy is instrumented. The IV model requires a valid instrument satisfying an exclusion restriction where the instrument which affects the endogenous variable (mother's literacy) does not have an independent causal effect on the outcome (fertility).

Finding such an instrument would be extremely difficult as the NFHS data do not cover or allow us to construct such a variable due to the inherent data constraints. In the present study, we use as an instrument the ratio of women who attended secondary school in the total in the age group 50 or above averaged at the village level. This is a proxy for general education levels or the availability of secondary education for grandmothers, which would affect mother's education, but not fertility directly because the village-level aggregation has at least partially eliminated the direct link between the fertility and the instrument. However, the validity of this instrument may be questioned for various conceptual grounds. For example, many women in India marry men outside the village, or better education in the previous generation reflects better information about child health and nutrition and preference for child quality over quantity. Given that the instrument is not perfect, the results will have to be interpreted with caution. However, we would argue that this instrument is one of the 
best ones due to the data constraints and it is justified as the specification passes various statistical tests for the validity of instruments (e.g. under-identification and weak identification tests presented at the bottom of Table 3). For pseudo panel data model we discuss below, we have included only the women aged from 19 to 33 years in the first round and thus the endogeneity issue is likely to be less relevant.

\section{(4) Pseudo Panel Data Model}

One of the limitations of the above model is that each round of NFHS is used separately for the cross-sectional estimations. To overcome this and to identify the determinants of fertility which are specific to a particular generation and common over the years, we apply the pseudo panel model which aggregates micro-level household data by any meaningful unit or cohort (e.g. geographical areas or age groups) that is common across cross-sectional data sets in different years. We apply the pseudo panel for the cohort $k$ based on the combination of states and rural-urban classifications. The cohort is denoted as $k$ in the equation (2) below.

$\bar{n}_{i k t}=\bar{n}_{i k t}\left({\overline{E_{i}^{m} k t}}_{A_{i k t}},{\overline{B_{i k t}}}_{\bar{O}_{i k t}},{\overline{M_{i k t}}}_{1}, \bar{L}_{i k t}, \bar{S}_{i k t}\right)$

where $k$ denotes cohort (i.e., age cohort $\times$ state $\times$ rural-urban classification) and $t$ stands for survey years for three rounds of NFHS, 1992, 1998 and 2005. The upper bar means that the average of each variable is taken for each cohort, $k$ for each round, $t$. As mother's education is highly correlated with father's at the aggregate level, we insert either $\overline{E_{t k t}^{m}}$ or $\overline{E_{t k t}^{f}}$ at one time.

The equation (2) can be estimated by the standard static panel model, such as fixed effects or random effects model.

$$
\bar{n}_{i k t}=\alpha+\sum_{l=1}^{q} \beta^{l} \bar{x}_{i k t}^{l}+\gamma D_{t}+\bar{\mu}_{k t}+\bar{e}_{k t}
$$


where $\bar{n}_{i k t}^{l}$ is a dependent variable, $\bar{x}_{i k t}^{l}$ is an explanatory variable such as $\overline{E_{i}^{M}}{ }_{k t}$, $D_{t}$ is the vector of year dummies, $\bar{\mu}_{k t}$ is the unobservable individual effect specific to the cohort $k$ (e.g. the infrastructure, the cultural effects which are not captured by explanatory variables), and $\overline{\boldsymbol{e}}_{k t}$ is an error term. The issue is whether the equation (3) is a good approximation of the underlying household panel models for household $i$ in the equation (3)' below. It is not straightforward to check this as we do not have 'real' panel data.

$n_{i t}=\alpha^{\prime}+\sum_{l=1}^{q} \beta^{\prime l} x_{i t}^{l}+\gamma^{\prime} D_{t}+\mu_{i}+e_{i t}$

However, as shown by Verbeek and Nijman (1992) and Verbeek (1996), if the number of observations in cohort $k$ tends to infinity, $\bar{\mu}_{k t} \rightarrow \mu_{k}{ }^{*}$ and the estimator is consistent. In our case, $k$ is reasonably large and thus the estimator is likely to be almost consistent. Once we take account of the cohort population, the equation (3) will become the model developed by Deaton (1985) whereby $\bar{n}_{i k t}$ and $\bar{x}_{i k t}$ are considered to be error-ridden measurements of unobservable cohort means, which leads to so-called 'error-in-variables estimator' (see Fuller, 1987 for more details).

We construct the cohort by multiplying three classifications: state, rural-urban category, and age groups. This approach has a merit of taking account of (a) geographical diversity of India, (b) age-group specific fertility behaviour and (c) right censoring arising from the fact that women in younger generations may not start their fertility periods if they take opportunities of higher education increasingly available in India in recent years. Mother's age groups have been constructed as (i) the first age cohort, 19-23 years, (ii) the second age cohort, 24-28 years, and (iii) the third age cohort, 29-33 years in 1992-93, (i) 25-29 years, (ii) 30-34 years, and (iii) 35-39 years in 1998-1999, and (i) 32-36 years, (ii) 37-41 years, and (iii) 42-46 years in 2005-2006. 


\section{Main Results}

In this section we will report and discuss econometric results for the models described in the previous section. The results of cross-sectional estimations for the first, second and third rounds of NFHS are reported in Table 3, while those of pseudo panel data model are shown in Table 4.

\section{(1) OLS, Ordered Logit, and IV Results for Households across all India}

Table 3 presents five cases for three rounds of NFHS, - Case (A): OLS model with literacy dummies for mother and father, Case (B): OLS model with a set of dummy variables of their educational attainments, Case (C): ordered logit with literacy dummies for mother and father, Case (D): ordered logit model with a set of dummy variables of their educational attainments, and Cade (E): IV model where literacy dummies are instrumented. ${ }^{17}$

\section{(Table 3 to be inserted)}

We first highlight the effects of education on fertility. In Case (A) (OLS) and Case (C) (ordered logit), the dummy variable on mother's literacy is all negative and significant for all the three rounds - with the coefficient estimate increasingly significant in the later rounds. The coefficient estimate of a mother's literacy dummy suggests that if a mother is literate, the number of children she has borne on average is likely to be reduced by $0.303,0.406$, and 0.610 in 1992, 1998 and 2005 respectively, ceteris paribus in Case (A) in which OLS is applied. The estimated reduction in the number of children is larger in Case (C) (ordered logit) - 0.322, 0.490, and 1.01 in 1992, 1998 and 2005 respectively. These reductions seem substantial in comparison with the average total fertility rate (TFR) as each figure of reduction corresponds to 
$9.6 \%, 14.2 \%$ and $22.8 \%$ of TFR in each year. It is also noted that the negative effect of mother's literacy on fertility is larger in more recent years in both Case (A) and Case (C). It is not clear only from our regression results why mother's literacy had an increasingly negative effect on the number of children. It is surmised, however, that if the average fertility of illiterate women has not changed dramatically, that of literate women (some of whom became more likely to receive secondary or higher education in later rounds) has been reduced over the years as a result of their increased autonomy and bargaining power in the household.

Father's literacy is negative and non-significant in 1992 and negative and significant in 1998 and 2005 with the coefficient estimate more significant in the last round in Case (A) (OLS). It is negative and significant only in 2005 in Case (C) (ordered logit). While the absolute values of coefficient estimates of father's literacy is much smaller than that of mother's literacy, it changes from -0.055 in 1992 , to 0.061 in 1998 and -0.290 in 2005 in Case (A). Mother's education is generally deemed a more important determinant of fertility than father's education because women are still responsible for childcare in a majority of households in India and thus the income forgone by giving up a job is likely to be larger for women than for men. However, father's literacy became increasingly important in the last round with its effect nearly half of the effect of mother's literacy in Case (A). The reason for this is not clear, but this might be due to some change in the bargaining relation between a husband and a wife in favour of the latter because it is likely that women became more and more educated and empowered in the later rounds, which might change the behavioral response of literate men who began to cooperate with family planning in recent years. 
The effects of dummy variables on educational attainment of mother and father have been examined in Case (B) (OLS) and Case (D) (ordered logit). For all the three levels (i.e. completed only primary school, only secondary or higher secondary school, and higher education), mother's education is negative and significant across all the three rounds in both cases. The absolute values of coefficient estimates are similar in 1992 and in 1998, but it is substantially larger for all the levels in 2005. For example, if a household has a mother completing only primary school, the number of children reduces by 0.21 (or 0.327) in 2005 in Case (B) (or Case (D)), ceteris paribus. This will increase to 0.58 (or 1.038) for completion of secondary or higher secondary school and 1.12 (or 2.00) for higher education in Case (B) (or Case (D)). This confirms the increasing role of mother's education as we have discussed above. On the role of father's education, the coefficient estimates of educational attainments are negative and significant except for primary education in the first two rounds and secondary or higher secondary school in the last round. While the results imply that father's education reduces the number of children, its marginal effects are much smaller than mother's education. Contrary to our expectation, the effect of father competing higher education was getting smaller in absolute terms over the years with the coefficient estimate changing from $-0.290,-0.247$ to -0.120 in Case (B) (or from $0.270,-0.227$ to 0.051 in Case (D)). The reason is again not clear, but it is noted that the effect of father's completing primary education in reducing fertility became relative larger in the last round $(-0.17)$ (the magnitude of which became closer to mother's completing primary education $(-0.21))$ in Case (B). That is, if men had basic or primary education, they would become able to, for example, understand the logic of family planning, or be willing to cooperate with women in the household 
bargaining, while completing secondary or higher education has a relatively small impact on fertility.

Case (E) reports the results of IV model. Given the limitation of our instrument, the results will have to be interpreted with caution. ${ }^{18}$ Though the coefficient estimates are less statistically significant, the pattern of the results for mother's literacy in Case (E) is similar to the corresponding results in Case (A) or Case (C). That is, the role of mother's literacy in reducing fertility has become more and more important in the later rounds. However, father's literacy is positive and significant in Case (E) in all the rounds. Since the reason is not clear and given the limitation of our instrument in Case (E), we would use Cases (A) and (C) as our preferred cases for the following discussion. $^{19}$

Our results confirm the greater role of female education in fertility reduction as emphasized by earlier studies, for example, Brookins and Brookins (2002), Drèze and Sen (2002), Drèze and Murthi (2001), Subbarao and Raney (1985), and Jain and Nag (1986). While Drèze and Murthi (2001) and Drèze and Sen (2002) claim that male literacy makes no contribution to reduction in fertility when controlled by female education, our study shows that both male literacy and education attainments are closely associated with fertility reduction in both OLS and ordered logit.

Turning to the results of other variables, all the cases for three rounds show that the coefficient estimate of mother's age is positive and significant and its square is negative and significant, which reflects the non-linearity in the age-fertility relationship. The coefficient estimate of Scheduled Caste (SC) dummy is positive and significant in both OLS and ordered logit, whilst that of scheduled tribe (ST) dummy is positive and significant only in the last round in these cases. ST dummy is negative and significant in Case (E) or IV across three rounds. The current results alone will 
not provide any clue as to why the fertility of SC households was higher than the rest throughout all three rounds and that of ST became higher only in the last round if we highlight the results in Cases (A)-(D). However, the recent study by Das and Tarai (2011) provides some clue for us. Using the NFHF-3 data on Orissa, they have shown that the index of empowerment or decision-making power on health care, financial matter or physical mobility does not influence fertility of women in SC or ST households. It can be thus conjectured that the women in SC who are likely to be more disadvantaged and less empowered than those in non-SC households were forced to follow the traditional view of 'large family' and to give birth to more children, though the same pattern is observed for ST women only in the last round. Why the sign of the coefficient estimate has been reversed for ST women is unclear and the future research should investigate the underlying causes for recent changes in the relation between fertility and social backwardness, such as belonging to ST.

Both agricultural and non-agricultural self-employment dummies have a positive sign in most of the cases. The positive sign may suggest that children are more valuable as labor inputs and demanded by the self-employed households than in other types of households.

The positive and significant effect of Scheduled Caste and Muslim dummies on fertility found in most of the cases is consistent with the earlier literature, for example, Mouhasha and Rama Rao (1999) and Bhat and Zavier (2005), implying that fertility is higher among Muslims than the rest. ${ }^{20}$ The number of children of a Muslim mother tends to be higher than the rest by 0.295 to 0.717 , ceteris paribus. We have obtained mixed results for the estimates of owned land. It is negative and significant in 1992 and 1998, while positive in 2005 for Cases (A)-(D). It is not clear why the sign was reversed in 2005 in these cases. In Case (E), it is negative and significant for NFHS-1 
and 3. The son preference dummy variable is mostly positive and significant in Cases (A)-(D), but it is negative and significant in Case (E) (IV) for NFHS-3. Taking OLS and ordered logit as our preferred cases, the positive coefficient estimate of son preference dummy implies that mothers who prefer sons tend to have more children and thus high fertility results. This is consistent with earlier studies, such as Drèze and Sen (2002).

\section{(2) Results of Pseudo Panel Model}

Table 4 presents the results based on pseudo panel models based on cohorts constructed by (a) age cohorts, (b) state, and (c) a rural and urban classification. A few points are noted on the selection of explanatory variables. First, we use education variables (literacy or a set of educational levels) separately for a father and a mother as they are correlated at the aggregate level. ${ }^{21}$ Second, the results based on fixedeffects model are presented following the results of Hausman tests which favour fixed effects models over random-effects models in all cases. Four cases are shown according to whether education is for mother or father and how education is defined, i.e. the literacy rate or the educational attainments. Case (A) is the case with mother's literacy rate, Case (B) is with father's literacy rate, Case (C) is the case with mother's educational attainments as shares, and Case (D) is with father's educational attainments. As we discussed, three age cohorts for mothers were traced for the entire period of 14 years from 1992 to 2006. As a robustness check to take account of right censoring, we have tried the cases only with the second and the third cohorts and those only with the third cohort. To save the space, only the cases with all 3 cohorts are presented in Table 4.

(Table 4 to be inserted) 
The results in Table 4 are broadly consistent with those in Table 3. Table 4 shows that coefficient estimates of variables on mother or father's education are mostly negative and significant regardless of the definition of education. It is noted that these negative effects are observed with similar patterns in the cases with the second and third age cohorts and those with the third age cohort only. ${ }^{22}$ Because pseudo panel involves averaging a dependent variable and explanatory variables within a cohort, there is little difference in the absolute values of coefficient estimates for mother's education and father's education. These results are important as we have taken account of (1) age-specific fertility behavior over the years, (2) time-series changes in fertility rates at regional cohort, and (3) right censoring due to the fact that young mothers may not start their fertility period if they participate in attend higher education. Our results are consistent with the role of parental education in reducing fertility rates in India.

On other variables, we obtain the coefficient estimates with same signs and significance as obtained by household data for mother's age (positive) and its square (negative), and non-agricultural self-employed dummies (positive). Those of Schedule Caste are negative and significant, which is consistent with the results of Table 3. Share of Muslim is positive and significant in Case (A) and Case (B). Son's preference index is statistically insignificant. This is probably because there is little inter-state variation in son's preference index (that is, the extent to which mother prefers son is not much different among different states) which resulted in insignificant coefficient estimates in the case of pseudo panel model, while the intrastate variation of the index has mainly driven the significant estimates in OLS in Table 3. 


\section{Concluding Observations}

This paper examines the determinants of fertility and its changes drawing upon three rounds of NFHS data over the period 1992-2006. That fertility declined dramatically in many parts of India during the period is consistent with the view that India is seen to be moving through the second stage toward the third stage of demographic transition. The investigation of fertility in India is important not only for providing an insight into the population problem for the second populous country in the world. It also serves as a background for the debate on poverty in India which would be influenced by the geographical pattern of population growth. This paper sheds an empirical light on the determinants of fertility by applying econometric models to the large household data sets constructed by NFHS data. Our main findings are summarized below.

Consistent with the literature, mother's education is related to reduction in fertility. We have confirmed a negative and significant association of the number of children and mother's education - defined in terms of both literacy and educational attainments. More importantly, the role of mother's education in reducing fertility became increasingly important over the years. The negative link between mother's education and fertility has been reported in the past (e.g. Drèze and Murthi, 2001), but the past studies used the district-level data or the data which aggregate the census data at district levels in the context of India. The present study is the first, to our knowledge, to show this link using the nation-wide household survey data. Our contribution to the literature has also been made by tracing the data over the period spanning from 1992 to 2006 and by confirming that the negative association between mother's education and fertility has become stronger in recent years. Furthermore, we have found 
significant and negative coefficient estimates for father's education in case of OLS and ordered logit. However, its effect is generally smaller than mother's education. Few studies have focused on the role of father's education on fertility and this is also a unique contribution of the present study.

The negative and significant effects of parental education have been observed when we run the pseudo panel regressions for age cohorts further classified by state, and rural-urban classification. The negative effect of education of parents is unchanged regardless of the definition of education and of the age cohorts to be included and it is consistent with the role of parental education in reducing fertility. The findings based on OLS and ordered logit have been confirmed by pseudo panel models by which age-group specific fertility behavior or time-series effects are taken into account.

Our econometric results identify other factors, such as, social backwardness, land owned or religion, which are important determinants of fertility. It is implied that the women in Scheduled Castes (SCs) who are likely to be more disadvantaged and less empowered than those belonging to non-SCs tend to have more children, while the results on Scheduled Tribe (ST) are mixed where both positive and negative coefficient estimates are found in different cases. We have also found that Muslim households tend to have more children than the rest.

Our results suggest that policies of national and state governments to support social infrastructure, such as school at various levels and to promote both male and female education, would be very important to reduce fertility and to speed down the population growth. These policies would play particularly important roles in backward states or for socially disadvantaged groups (e.g. Scheduled Castes) which have higher fertility as well as poverty rates. 


\section{References}

Bardhan, P. \& Udry, C. (1999) Development Microeconomics (New York: Oxford University Press).

Basu, K. (2006) Gender and Say: a Model of Household Behaviour with Endogenously Determined Balance of Power, The Economic Journal, 116, pp. $558-580$

Becker, G. S. (1960) An Economic Analysis of Fertility, in Demographic and Economic Change in Developed Countries: a conference of the UniversitiesNational Bureau Committee for Economic Research. ed. George B. Roberts (Chairman, Universities-National Bureau Committee for Economic Research) (New York: Princeton University Press), pp.209-240.

Becker, G. S. (1981) A Treatise on the Family (Cambridge: Harvard University Press).

Becker, G. S. \& Lewis, H. G. (1973) On the Interaction between Quantity and Quality of Children, Journal of Political Economy, 81, pp.S279-S288.

Bhalotra, S. \& van Soest, A. (2008) Birth-Spacing, Fertility and Neonatal Mortality in India: Dynamics, Frailty, and Fecundity, Journal of Econometrics, 143, pp.274290.

Bhat, P. N. M., (2002) Returning a Favor: Reciprocity Between Female Education and Fertility in India, World Development, 30(10), pp.1791-1803.

Bhat, P. N. M. \& Zavier, A. J. F. (2005) Role of Religion in Fertility Decline, Economic \& Political Weekly, 40(5), pp.385-402, January 29.

Bose, A. (2000) North-South Divide in India's Demographic Scene, Economic and Political Weekly, pp.1698-1699, May 13.

Brookins, M. L. \& Brookins, O. T. (2002) An exploratory analysis of fertility differentials in India, Journal of Development Studies, 39(2), pp.54-72. 
Browning, M. \& Chiappori, P. A. (1998) Efficient Intra-Household Allocations, Econometrica, 66(6), pp.1241-1278.

Browning, M. \& Gørtz, M. (2012) Spending Time and Money within the Household, Scandinavian Journal of Economics, 114(3), pp. 681-704.

Das, B. \& Tarai, D. (2011) Decision-making and Fertility Behaviour: A Comparative Analysis of Scheduled Caste and Scheduled Tribe Women in Odisha, Social Change, 41(2), pp.233-249.

Deaton, A. (1985) Panel Data from the Time Series of Cross-Sections, Journal of Econometrics, 30, pp.109-126.

Drèze, J. \& Sen, A. (2002) India: Development and Participation (New Delhi, Oxford University Press).

Drèze, J. \& Murthi, M. (2001) Fertility, Education and Development, Population and Development Review, 27(1), pp.33-63.

Fuller, W. A. (1987) Measurement Error Models, Wiley and Sons, New York.

Greene, W. (2003) Econometric Analysis, Fifth Edition, Prentice Hall, New Jersey.

Himanshu (2007) Recent Trends in Poverty and Inequality: Some Preliminary Results, Economic and Political Weekly 42, pp.497-508, February 10.

International Institute for Population Science (2001) National Family Health Survey: India 1998-99 (Mumbai, IIPS).

Imai, K. \& Sato, T. (2010) Fertility, Parental Education and Development in India: Evidence from National Household Survey Data, RIEB Discussion Paper Series DP2010-17 (Kobe: Kobe University).

Imai, K., Annim, S.K., Gaiha, R., and Kulkarni, V.S. (2012) Does Women's Empowerment Reduce Prevalence of Stunted and Underweight Children in Rural India?, RIEB Discussion Paper Series DP2012-11 (Kobe: Kobe University). 
Jain, A. \& Nag, M. (1986) The Importance of Female Primary Education for Fertility Reduction in India, Economic and Political Weekly, 21(36), pp.1602-1608, September 6 .

Mahbub ul Haq Human Development Center (2002) Human Development in South Asia 2001 Globalisation and Human Development (Karachi, Oxford University Press).

Mishra, V. (2004) 'Muslim/Non-Muslim Differentials in Fertility and Family Planning in India', East-West Center Working Papers- Population Health Series No. 122, Jan 2004.

Moulasha, K. \& Rao, G. R. (1999) Religion-Specific Differentials in Fertility and Family Planning, Economic and Political Weekly, 34(42-43), pp.3047-51, October $16-23$.

Vallely, P. (2008) Population paradox: Europe's time bomb, The article in the $\begin{array}{lll}\text { Independent, } & \text { August } & 9,\end{array}$ http://www.independent.co.uk/news/world/europe/population-paradox-europestime-bomb-888030.html.

Rosenzweig, M. (1990) Population growth and human capital investments: theory and evidence, Journal of Political Economy, 98(5), pp.S12- S70.

Singh, A. (2001) 'Education, Fertility and Fertility Preferences', on-line article, http://news.wikinut.com/Education,-Fertility-and-Fertility-Preferences/rwgg_59f/ (accessed on $30^{\text {th }}$ September 2011).

Subbarao, K. \& Raney, L. (1995) Social Gains from Female Education, Economic Development and Cultural Change, 44, pp.105-28.

Sujatha, D. S. \& Reddy, G. B. (2009) Women's Education, Autonomy and Fertility Behaviour, Asia-Pacific Journal of Social Sciences, 1(1), pp.35-50. 
United Nations (2012) World Population Prospects: The 2011 Revision (New York, Population Division of the Department of Economic and Social Affairs of the United Nations Secretariat).

Verbeek, M. (1996) Pseudo Panel Data in Matyas, L. \& Sevestre, P. (Eds.), The econometrics of panel data: A handbook of the theory with applications, second edition, in Advanced Studies in Theoretical and Applied Econometrics, vol. 33. (Boston and London, Kluwer Academic), pp. 280-92.

Verbeek, M. \& Nijman T. E. (1992) Can Cohort Data Be Treated As Genuine Panel Data? Empirical Economics 17, pp.9-23.

World Bank (2012) World Development Report 2012: Gender Equality and Development (New York, Oxford University Press). 
Table 1 Population Projection for India, China, Sub-Saharan Africa and World in 2005

\begin{tabular}{ccccc} 
& India & China & SSA $^{* 2}$ & World \\
\hline \multirow{2}{*}{1980} & 700 & 983 & 375 & 4453 \\
& $(15.7 \%)$ & $(22.1 \%)$ & $(8.4 \%)$ & $(100 \%)$ \\
2010 & 1225 & 1341 & 823 & 6896 \\
& $(17.8 \%)$ & $(19.4 \%)$ & $(11.9 \%)$ & $(100 \%)$ \\
2050 & 1692 & 1296 & 1892 & 9306 \\
& $(18.2 \%)$ & $(13.9 \%)$ & $(20.3 \%)$ & $(100 \%)$ \\
\hline
\end{tabular}

${ }^{*}$. Unit: million. The number in the brackets: share in the world.

*2. Sub-Saharan Countries total.

*3. Source: UN (2012). The figures in 2050 are the estimate of medium variant.

Table 2 Total Fertility Rate for $15-49$ in India based on NFHS-1, 2 and 3 (1992-3, 1998-9 and 2005-6)

\begin{tabular}{cccccccccc}
\hline & \multicolumn{3}{c}{ URBAN } & \multicolumn{3}{c}{ RURAL } & \multicolumn{3}{c}{ Total } \\
& 1992 & 1998 & 2005 & 1992 & 1998 & 2005 & 1992 & 1998 & 2005 \\
\hline North & 2.69 & 2.15 & 1.95 & 3.60 & 2.98 & 2.68 & 3.32 & 2.71 & 2.43 \\
Central & 3.43 & 2.75 & 2.66 & 4.65 & 3.94 & 3.64 & 4.36 & 3.65 & 3.37 \\
East & 2.64 & 2.21 & 2.04 & 3.46 & 2.86 & 3.04 & 3.28 & 2.75 & 2.82 \\
Northeast & 2.53 & 2.08 & 2.09 & 2.70 & 3.43 & 3.17 & 3.31 & 3.12 & 2.87 \\
West & 2.33 & 2.09 & 1.87 & 2.76 & 2.53 & 2.31 & 2.58 & 2.34 & 2.11 \\
South & 2.22 & 1.90 & 1.76 & 2.60 & 2.22 & 1.99 & 2.48 & 2.13 & 1.90 \\
\hline All India & 2.70 & 2.27 & 2.06 & 3.67 & 3.07 & 2.98 & 3.39 & 2.85 & 2.68 \\
\hline
\end{tabular}

Source: Based on National Familiy Health Survey in 1998-99 and 2005-6 (Table 4.3) 
Table 3 Determinants of fertility in India (OLS, Ordered Logit Model and IV Model for cross-sectional household data)

\begin{tabular}{|c|c|c|c|c|c|c|c|c|c|c|c|c|c|c|c|}
\hline & \multicolumn{5}{|c|}{ NFHS-1 (1992/3) } & \multicolumn{5}{|c|}{ NFHS-2 (1998/9) } & \multicolumn{5}{|c|}{ NFHS-3 (2005/6) } \\
\hline & Case (A) & Case (B) & Case (C) & Case (D) & Case (E) & Case $(A)$ & Case (B) & Case $(\mathrm{C})$ & Case (D) & Case (E) & Case $(A)$ & Case (B) & Case (C) & Case (D) & Case $(E)$ \\
\hline & OLS & OLS & $\begin{array}{c}\text { Ordered } \\
\text { Logit }\end{array}$ & $\begin{array}{c}\text { Ordered } \\
\text { Logit }\end{array}$ & IV & OLS & OLS & $\begin{array}{c}\text { Ordered } \\
\text { Logit }\end{array}$ & $\begin{array}{c}\text { Ordered } \\
\text { Logit }\end{array}$ & IV & OLS & OLS & $\begin{array}{c}\text { Ordered } \\
\text { Logit }\end{array}$ & $\begin{array}{c}\text { Ordered } \\
\text { Logit }\end{array}$ & IV \\
\hline Explanatory Variables & $\begin{array}{c}\text { Coef. } \\
\text { (t value) }\end{array}$ & $\begin{array}{c}\text { Coef. } \\
\text { (t value) }\end{array}$ & $\begin{array}{l}\text { Coef. } \\
\text { (t value) }\end{array}$ & $\begin{array}{l}\text { Coef. } \\
\text { (t value) }\end{array}$ & $\begin{array}{l}\text { Coef. } \\
\text { (t value) }\end{array}$ & $\begin{array}{l}\text { Coef. } \\
\text { (t value) }\end{array}$ & $\begin{array}{l}\text { Coef. } \\
\text { (t value) }\end{array}$ & $\begin{array}{l}\text { Coef. } \\
\text { (t value) }\end{array}$ & $\begin{array}{l}\text { Coef. } \\
\text { (t value) }\end{array}$ & $\begin{array}{c}\text { Coef. } \\
\text { (t value) }\end{array}$ & $\begin{array}{c}\text { Coef. } \\
\text { (t value) }\end{array}$ & $\begin{array}{c}\text { Coef. } \\
\text { (t value) }\end{array}$ & $\begin{array}{c}\text { Coef. } \\
\text { (t value) }\end{array}$ & $\begin{array}{l}\text { Coef. } \\
\text { (t value) }\end{array}$ & $\begin{array}{l}\text { Coef. } \\
\text { (t value) }\end{array}$ \\
\hline Mother's Age & $\begin{array}{c}0.221 \\
(18.26)^{* *}\end{array}$ & $\begin{array}{c}0.23 \\
(18.82)^{\star *}\end{array}$ & $\begin{array}{c}0.41 \\
(27.58)^{\star *}\end{array}$ & $\begin{array}{c}0.42 \\
(28.21)^{\star *}\end{array}$ & $\begin{array}{c}0.240 \\
(16.57)^{\star *}\end{array}$ & $\begin{array}{c}0.211 \\
(28.70)^{\star *}\end{array}$ & $\begin{array}{c}0.222 \\
(30.36)^{\star *}\end{array}$ & $\begin{array}{c}0.41 \\
(40.59)^{* *}\end{array}$ & $\begin{array}{c}0.43 \\
(42.62)^{* *}\end{array}$ & $\begin{array}{c}0.188 \\
(16.35)^{\star *}\end{array}$ & $\begin{array}{c}0.185 \\
(50.46)^{\star *}\end{array}$ & $\begin{array}{c}0.261 \\
(47.70)^{* *}\end{array}$ & $\begin{array}{c}0.686 \\
(75.32)^{\star *}\end{array}$ & $\begin{array}{c}0.543 \\
(53.83)^{\star *}\end{array}$ & $\begin{array}{c}0.096 \\
(14.91)^{*} \\
*\end{array}$ \\
\hline$(\text { Mother's Age })^{2}$ & -0.001 & -0.086 & -0.004 & -0.004 & -0.002 & -0.001 & -0.001 & -0.004 & -0.004 & -0.001 & -0.001 & -0.003 & -0.007 & -0.005 & 0.0001 \\
\hline Scheduled Tribe ( & $(6.05)^{\star *}$ & $(6.78)^{* *}$ & $(16.51)^{* *}$ & $(17.30)^{* \star}$ & $(6.30)^{\star *}$ & $(11.12)^{\star *}$ & $(12.82)^{\star *}$ & $(24.59)^{* \star}$ & $(26.68)^{* *}$ & $(7.61)^{\star \star}$ & $(20.44)^{* *}$ & $(27.04)^{* *}$ & $(55.68)^{\star *}$ & $(36.06)^{\star *}$ & $(1.29)$ \\
\hline$(\mathrm{ST}=1$, otherwise $=0)$ & -0.082 & -0.086 & -0.040 & -0.004 & -0.293 & 0.048 & 0.016 & 0.048 & 0.001 & -0.434 & 0.124 & 0.249 & 0.207 & -0.360 & -0.081 \\
\hline & (1.48) & $(1.56)$ & $(0.66)$ & $(0.71)$ & $(3.13)^{\star \star}$ & $(1.27)$ & $(0.44)$ & $(1.10)$ & $(0.03)$ & $(3.77)^{\star \star}$ & $(4.78)^{\star \star}$ & $(7.09)^{\star \star}$ & $(4.76)^{\star \star}$ & $(7.85)^{\star \star}$ & $(2.34)^{\star *}$ \\
\hline $\begin{array}{l}\text { Scheduled Caste }(\mathrm{SC}) \text { dummy } \\
\quad(\mathrm{SC}=1 \text {, otherwise }=0)\end{array}$ & 0.267 & 0.242 & 0.250 & 0.230 & 0.070 & 0.273 & 0.206 & 0.309 & 0.222 & -0.252 & 0.181 & 0.234 & 0.380 & 0.384 & -0.033 \\
\hline & $(4.75)^{\star \star}$ & $(4.31)^{\star \star}$ & $(4.12)^{\star \star}$ & $(3.77)^{\star \star}$ & $(0.77)$ & $(10.04)^{\star \star}$ & $(7.55)^{\star \star}$ & $(9.67)^{\star \star}$ & $(6.92)^{\star \star}$ & $(2.11)^{*}$ & $(9.78)^{\star \star}$ & $(9.33)^{\star *}$ & $(11.33)^{\star *}$ & $(10.79)^{* *}$ & $(1.26)$ \\
\hline employment=1 otherwise) & 0.194 & 0.071 & 0.215 & 0.074 & -0.032 & 0.016 & 0.006 & 0.019 & 0.007 & 0.150 & 0.035 & 0.04 & 0.369 & 0.017 & 0.186 \\
\hline & $(4.35)^{* \star}$ & $(1.49)$ & $(3.98)^{\star *}$ & $(1.29)$ & $(0.35)$ & $(0.67)$ & $(0.24)$ & $(0.62)$ & $(0.21)$ & $(3.44)^{\star \star}$ & $(2.20)^{\star *}$ & $(2.48)^{\star}$ & $(14.49)^{\star *}$ & $(0.66)$ & $(8.98)^{\star *}$ \\
\hline $\begin{array}{l}\text { agricultural self employment } \\
\text { dummy (agricultural self } \\
\text { employment=1 otherwise }=0 \text { ) *3 }\end{array}$ & 0.209 & 0.068 & 0.233 & 0.076 & -0.152 & 0.069 & 0.009 & 0.010 & 0.025 & -0.217 & - & - & - & - & - \\
\hline & $(4.56)^{\star \star}$ & (1.38) & $(4.36)^{* \star}$ & (1.33) & (1.12) & $(2.88)^{\star \star}$ & $(0.39)$ & $(3.53)^{\star \star}$ & $(0.86)$ & $(3.06)^{\star *}$ & - & - & - & - & - \\
\hline Land Owned (1/1000 ha) & -0.001 & -0.000 & -0.002 & -0.002 & -0.0007 & -0.004 & -0.004 & -0.006 & -0.005 & -0.005 & 0.006 & 0.015 & 0.026 & 0.045 & 0.002 \\
\hline & $(3.40)^{\star *}$ & $(3.05)^{*}$ & $(3.51)^{*}$ & $(3.24)^{\star *}$ & $(1.88) \dagger$ & $(1.89) \dagger$ & $(1.80) \dagger$ & $(2.37)^{*}$ & $(2.21)^{*}$ & $(2.13)^{\star}$ & $(5.51)^{\star \star}$ & $(7.85)^{* *}$ & $(13.76)^{* *}$ & $(16.71)^{* \star}$ & $(1.71) \dagger$ \\
\hline otherwise $=0$ ) & 0.325 & 0.295 & 0.338 & 0.301 & 0.210 & 0.509 & 0.404 & 0.603 & 0.467 & 0.050 & 0.382 & 0.54 & 0.801 & 0.879 & 0.116 \\
\hline & $(4.39)^{\star *}$ & $(3.96)^{\star \star}$ & $(4.54)^{\star \star}$ & $(4.00)^{* \star}$ & $(2.40)^{*}$ & $(13.31)^{\star *}$ & $(10.54)^{\star *}$ & $(14.15)^{\star \star}$ & $(10.84)^{* *}$ & $(0.45)$ & $(16.34)^{\star \star}$ & $(16.49)^{\star *}$ & $(20.05)^{\star *}$ & $(20.36)^{* *}$ & $(3.58)^{\star *}$ \\
\hline $\begin{array}{c}\text { Mother's Literacy } \\
\text { (whether mother literate) }\end{array}$ & $\begin{array}{l}-0.303 \\
(8.25)^{* *}\end{array}$ & - & $\begin{array}{l}-0.322 \\
(7.39)^{\star *}\end{array}$ & - & $\begin{array}{l}-1.983 \\
(3.36)^{\star *}\end{array}$ & $\begin{array}{c}-0.406 \\
(17.29)^{* *}\end{array}$ & - & $\begin{array}{c}-0.49 \\
(17.55)^{\star *}\end{array}$ & - & $\begin{array}{l}-3.868 \\
(5.19)^{* *}\end{array}$ & $\begin{array}{c}-0.61 \\
(35.36)^{* *}\end{array}$ & - & $\begin{array}{c}-1.01 \\
(42.25)^{* *}\end{array}$ & - & $\begin{array}{c}-3.033 \\
(22.96)^{*} \\
*\end{array}$ \\
\hline
\end{tabular}




\begin{tabular}{|c|c|c|c|c|c|c|c|c|c|c|c|c|c|c|c|}
\hline Father's Literacy & -0.055 & - & -0.05 & - & 0.458 & -0.061 & - & -0.03 & - & 1.225 & -0.29 & - & -0.407 & - & $\begin{array}{c}0.852 \\
(11.88)^{*}\end{array}$ \\
\hline $\begin{array}{l}\text { (whether father literate) } \\
\text { Whether mother completed }\end{array}$ & $(1.38)$ & - & $(1.29)$ & - & $(2.42)^{*}$ & $(2.19)^{*}$ & - & $(0.96)$ & - & $(4.40)^{* *}$ & $(10.63)^{* *}$ & - & $(11.56)^{* *}$ & $\cdot$ & ${ }^{*}$ \\
\hline primary school & - & -0.14 & - & -0.13 & - & - & -0.137 & - & -0.134 & - & - & -0.21 & - & -0.327 & - \\
\hline Whather mother comnleted & - & $(3.31)^{* *}$ & - & $(2.64)^{* *}$ & - & - & $(4.83)^{* *}$ & - & $(3.95)^{\star \star}$ & - & - & $(7.52)^{\star *}$ & - & $(8.62)^{* \star}$ & - \\
\hline $\begin{array}{l}\text { secondary or higher } \\
\text { secondary school }\end{array}$ & - & -0.38 & - & -0.44 & - & - & -0.388 & - & -0.487 & - & - & -0.58 & - & -1.038 & - \\
\hline Whether mother completed & - & $(8.64)^{* \star}$ & - & $(7.50)^{* *}$ & - & - & $(14.33)^{* *}$ & - & $(13.90)^{* *}$ & - & - & $(27.85)^{\star *}$ & . & $(33.08)^{* *}$ & - \\
\hline higher education & - & -0.86 & - & -1.11 & - & - & -0.851 & - & -1.17 & - & - & -1.12 & - & -2.00 & - \\
\hline Whether father comnleted & - & $(10.92)^{* *}$ & - & $(8.53)^{* *}$ & - & - & $(24.88)^{* *}$ & - & $(23.30)^{* *}$ & - & - & $(44.65)^{\star *}$ & . & $(44.25)^{* *}$ & - \\
\hline $\begin{array}{l}\text { Wnetner tatner school } \\
\text { primary scea }\end{array}$ & - & -0.01 & - & -0.01 & - & - & 0.052 & - & 0.101 & - & - & -0.17 & - & -0.328 & - \\
\hline Whether father completed & - & $(0.10)$ & - & $(0.26)$ & - & - & $(1.58)$ & - & $(2.77)^{\star *}$ & - & - & $(5.42)^{\star *}$ & - & $(8.00)^{* *}$ & - \\
\hline secondary school & - & -0.13 & - & -0.12 & - & - & -0.079 & - & -0.045 & - & - & -0.02 & - & 0.028 & - \\
\hline Whether & - & $(2.82)^{* *}$ & - & $(2.28)^{*}$ & - & - & $(2.63)^{* *}$ & - & $(1.31)^{* *}$ & - & - & $(0.67)$ & $\cdot$ & $(0.74)$ & - \\
\hline higher education & - & -0.29 & - & -0.27 & - & - & -0.247 & - & -0.227 & - & - & -0.12 & - & 0.051 & - \\
\hline rural sector dummy (rural=1 & - & $(4.20)^{* *}$ & - & $(3.08)^{* *}$ & - & - & $(6.91)^{* *}$ & - & $(5.07)^{\star \star}$ & - & - & $(3.60)^{* *}$ & - & $(1.04)$ & - \\
\hline urban $=0$ ) & 0.199 & 0.114 & 0.207 & 0.093 & -0.047 & 0.302 & 0.181 & 0.368 & 0.200 & -0.294 & 0.218 & 0.187 & 0.488 & 0.289 & -0.092 \\
\hline & $(4.31)^{* *}$ & $(2.42)^{*}$ & $(3.81)^{* *}$ & $(1.68)^{*}$ & $(0.48)$ & $(13.29)^{* *}$ & $(7.85)^{* *}$ & $(12.98)^{*}$ & $(6.87)^{\star \star}$ & $(2.20)^{*}$ & $(15.93)^{* *}$ & $(9.85)^{\star *}$ & $(19.18)^{* *}$ & $(10.58)^{*}$ & $(3.79)^{* *}$ \\
\hline Son's Preference Dummy & $\begin{array}{c}0.106 \\
(3.19)^{* *}\end{array}$ & $\begin{array}{c}0.096 \\
(2.89)^{* *}\end{array}$ & $\begin{array}{c}0.129 \\
(3.50)^{* *}\end{array}$ & $\begin{array}{c}0.113 \\
(3.06)^{* *}\end{array}$ & $\begin{array}{l}0.002 \\
(0.03)\end{array}$ & $\begin{array}{c}0.255 \\
(10.90)^{* *}\end{array}$ & $\begin{array}{c}0.211 \\
(9.08)^{\star \star *}\end{array}$ & $\begin{array}{c}0.309 \\
(11.52)^{* *}\end{array}$ & $\begin{array}{c}0.251 \\
(9.32)^{\star \star}\end{array}$ & $\begin{array}{l}-0.013 \\
(0.19)\end{array}$ & $\begin{array}{l}0.089 \\
(4.81)^{* \star}\end{array}$ & $\begin{array}{l}0.007 \\
(0.30)\end{array}$ & $\begin{array}{l}-0.015 \\
(0.53)\end{array}$ & $\begin{array}{l}-0.142 \\
(4.70)^{* *}\end{array}$ & $\begin{array}{c}-0.516 \\
\underset{\star}{(12.57)^{\star}}\end{array}$ \\
\hline Number of Adults & $\begin{array}{c}0.075 \\
(9.33)^{* *}\end{array}$ & $\begin{array}{c}0.08 \\
(2.89)^{* *}\end{array}$ & $\begin{array}{c}0.054 \\
(5.92)^{* *}\end{array}$ & $\begin{array}{c}0.058 \\
(6.43)^{* *}\end{array}$ & $\begin{array}{c}0.099 \\
(8.57)^{* *}\end{array}$ & $\begin{array}{c}0.097 \\
(18.37)^{* *}\end{array}$ & $\begin{array}{c}0.101 \\
(19.23)^{* *}\end{array}$ & $\begin{array}{c}0.090 \\
(14.10)^{* *}\end{array}$ & $\begin{array}{c}0.094 \\
(14.64)^{* *}\end{array}$ & $\begin{array}{c}0.148 \\
(11.47)^{* *}\end{array}$ & $\begin{array}{l}0.089 \\
(4.81)^{* *}\end{array}$ & $\begin{array}{c}0.131 \\
(24.82)^{* *}\end{array}$ & $\begin{array}{c}0.075 \\
(11.48)^{* *}\end{array}$ & $\begin{array}{c}0.172 \\
(23.48)^{* *}\end{array}$ & $\begin{array}{c}0.124 \\
(22.25)^{\star}\end{array}$ \\
\hline Constant & $\begin{array}{r}-4.00 \\
(20.36)\end{array}$ & $\begin{array}{c}-3.898 \\
(19.88)\end{array}$ & - & - & $\begin{array}{c}-3.38 \\
(11.11)\end{array}$ & $\begin{array}{c}-3.60 \\
(29.72)\end{array}$ & $\begin{array}{c}-3.62 \\
(30.24)\end{array}$ & - & - & $\begin{array}{l}-1.45 \\
(2.95)\end{array}$ & $\begin{array}{c}-2.99 \\
(41.82)\end{array}$ & $\begin{array}{c}-4.72 \\
(45.93)\end{array}$ & - & - & $\begin{array}{l}-0.52 \\
(3.37)\end{array}$ \\
\hline Observations & 11726 & 11663 & 11726 & 11663 & 11596 & 26955 & 26872 & 26955 & 26878 & 26955 & 47441 & 35376 & 47441 & 35376 & 47361 \\
\hline (Pseudo) R-squared 4. & 0.48 & 0.49 & 0.17 & 0.17 & $\cdot$ & 0.45 & 0.47 & 0.17 & 0.17 & - & 0.55 & 0.46 & 0.28 & 0.19 & - \\
\hline
\end{tabular}




\begin{tabular}{|c|c|c|c|c|c|c|c|c|c|c|c|c|c|c|c|}
\hline Joint Significant Test & $\begin{array}{l}F(37,11688) \\
=368.15^{\star *}\end{array}$ & $\begin{array}{l}F(41,11621) \\
=336.65^{* \star}\end{array}$ & $\begin{array}{l}\text { LR Chi2(37) } \\
=8158^{* *}\end{array}$ & $\begin{array}{l}\text { LR Chi2(41) } \\
=8231^{* *}\end{array}$ & $\begin{array}{l}F(37,11558) \\
=284.07^{\star *}\end{array}$ & $\begin{array}{c}F(38,26916) \\
=690.71^{* *}\end{array}$ & $\begin{array}{c}F(42,26829) \\
=658.06^{\star *}\end{array}$ & $\begin{array}{l}\text { LR Chi2(37) } \\
=17671^{* \star}\end{array}$ & $\begin{array}{l}\text { LR Chi2(41) } \\
=18422^{\star *}\end{array}$ & $\begin{array}{c}F(37,26917) \\
=324.11^{\star *}\end{array}$ & $\begin{array}{l}F(32,47441) \\
=2364.91^{* *}\end{array}$ & $\begin{array}{l}F(36,35339) \\
=849.20^{* *}\end{array}$ & $\begin{array}{l}\text { LR Chi2(32) } \\
=43916^{* \star}\end{array}$ & $\begin{array}{l}\text { LR Chi(36) } \\
=24108^{* *}\end{array}$ & $\begin{array}{c}F(32,473 \\
28) \\
=1420.0^{*} \\
*\end{array}$ \\
\hline $\begin{array}{l}\text { Coefficient estimate and } z \text { statistics } \\
\text { of instruments in the first stage } \\
\text { For Mother's literacy } \\
\text { The availability of education } \\
\text { for grandmothers at village } \\
\text { level }\end{array}$ & - & - & - & - & $\begin{array}{l}-0.330 \\
(7.56)^{* *}\end{array}$ & - & - & & - & $\begin{array}{l}-0.239 \\
(6.78)^{* *}\end{array}$ & - & - & & - & $\begin{array}{c}-0.256 \\
(31.15)^{*} \\
*\end{array}$ \\
\hline $\begin{array}{l}\text { Under identification test (Kleibergen- } \\
\text { Paap rk LM statistic) }\end{array}$ & - & - & - & - & $61.494^{* *}$ & - & - & & - & $45.273^{* *}$ & - & - & & - & $\underset{* *}{914.940}$ \\
\hline $\begin{array}{l}\text { Weak identification test (Kleibergen- } \\
\text { Paap rk Wald F statistic) }\end{array}$ & - & - & - & - & $57.203^{* *}$ & - & - & & - & $45.918^{* *}$ & - & - & & - & $\underset{* *}{970.534}$ \\
\hline
\end{tabular}

Notes 1. Robust t statistics in parentheses. ${ }^{* *}$ significant at $1 \% ;{ }^{*}$ significant at $5 \% ; \dagger^{*}$ significant at $10 \%$.

2. State dummies are included in the regressions, but are omitted to save the space.

mployment in NFHS-3 and thus they are dropped.

4. Pseudo R-squared is presented in case of ordered logit model. 
Table 4 Determinants of fertility in India: Pseudo panel data model using age groupstate cohort, 1992-2006

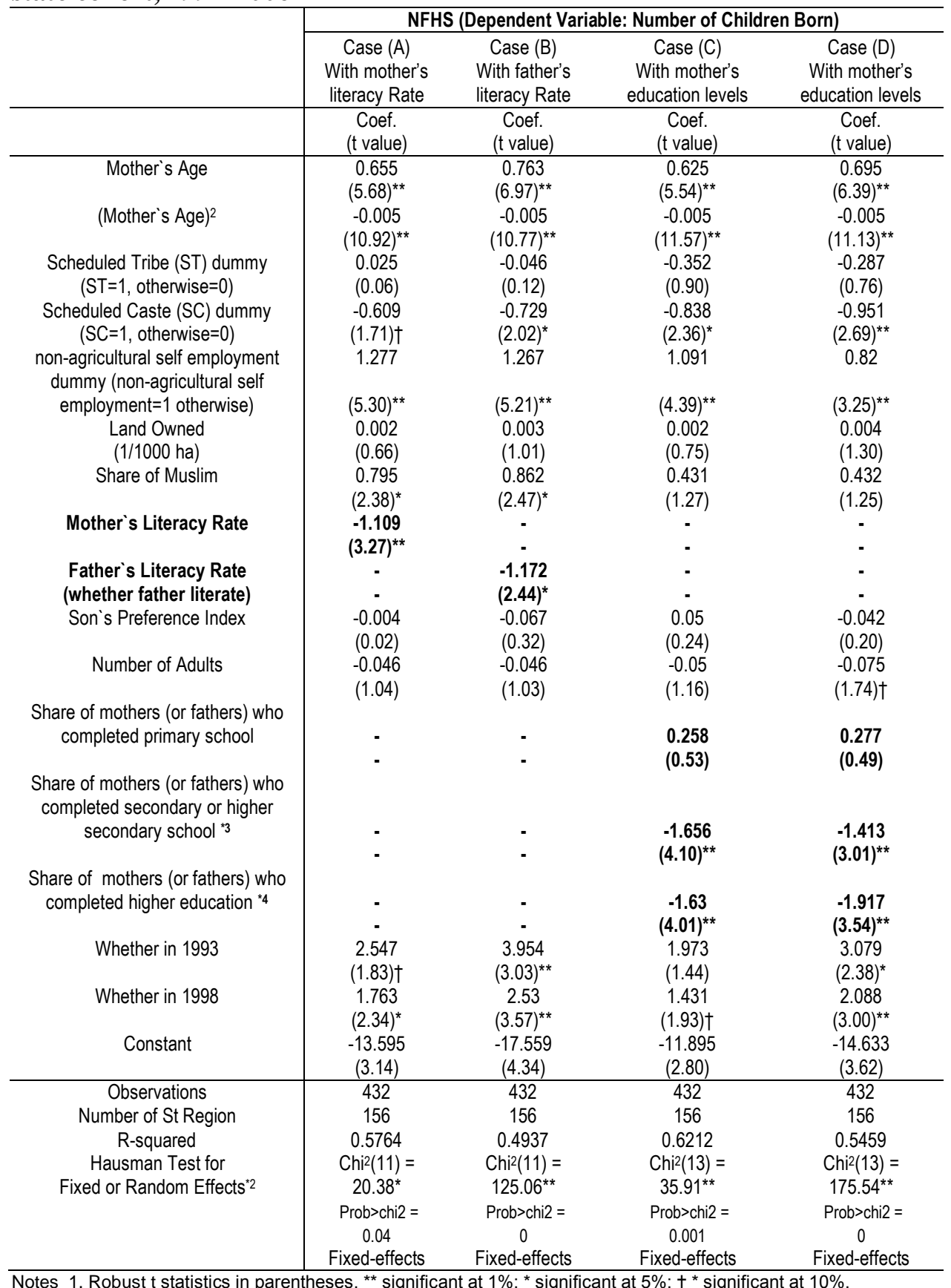

2. The choice of fixed or random effects model is based on $5 \%$ significance of Hausman Test results. 


\section{Notes}

${ }^{1}$ See Vallely (2008) for the debate on this issue.

${ }^{2}$ Poverty head count ratio based on the national poverty line in 2004/5 is 28.7\% (Himanshu, 2007).

${ }^{3}$ The theory of demographic transition explains the common pattern of transition in population history. While the first stage of transition before economic modernisation sees stable population due to high birth and death rates, the population grows rapidly in the second stage where death rates decline more rapidly than birth rates, for example, through better educational systems and medical and health care facilities only available in modernised society. The population becomes stable again in the third stage when further modernisation and better education cause fertility to go down.

${ }^{4}$ For example, the average annual growth rate of GDP per capita of India in 1992-2006 is $4.7 \%$, while the primary and secondary school enrolment increased from $70.1 \%$ in 1992 to $90.2 \%$ in 2006 (calculated by World Development Indicator 2010).

${ }^{5}$ Browning and Gørtz (2012) found that in Denmark women's relative expenditures (over men's) are positively influenced by their higher relative wages, but women's relative leisure is negatively affected by their relative wages. As women with a higher bargaining power who tend to have less leisure are likely to have fewer children to avoid their leisure time being further squeezed, Browning and Gørtz's results seem consistent with a negative effect of women's bargaining on fertility. The bargaining-fertility relationship is thus complex, but we consider only the general effect of education on fertility due to the data constraints.

${ }^{6}$ It is assumed here that the bargaining coefficient, $\gamma$ is exogenously determined by, e.g., female education or cultural factors, in other words, $\gamma$ affects the household decision on the number of children, but not the other way around. However, the bargaining coefficient, $\gamma$, can be endogenous in reality, that is, the household decision on the number of children could in turn affect $\gamma$ as modelled by Basu (2006) who assumes the endogeneity of $\gamma$ in the collective bargaining model. This endogeneity is not taken into account in the present analysis.

${ }^{7}$ While we assume that only parental education affects the bargaining power in the model due to the data constraints, other factors, such as, the difference in ages or labour participation of parents could affect the relative bargaining power (e.g. Imai et al. 2012). It is possible that the preferences $A_{i}$ may reflect some factors influencing the bargaining, but we have not modelled the interactions explicitly. As we primarily focus on the effects of parental education, rather than bargaining, on fertility in the present study, we do not use any proxy for the intra-household bargaining in our econometric models.

${ }^{8}$ As the NFHS data do not have income or consumption data, the relation between fertility and income cannot be examined. We have instead estimated the effect of owned land on the fertility and have found a negative and significant coefficient estimate.

${ }^{9}$ See http://www.nfhsindia.org/index.html for the detailed description of NFHS.

${ }^{10}$ TFR is the average number of children that would be born to a woman over her lifetime if she were to experience the exact current age-specific fertility rates through her lifetime, and she were to survive from birth through the end of her reproductive life.

${ }^{11}$ Given the presence of heteroskedasticity in our large sample, we have opted for robust OLS model by using the White-Huber sandwich estimator, not robust Tobit model, because the latter is likely to be inconsistent with heteroskedasticity (Greene, 2003). We owe this useful comment to one of the referees.

${ }^{12}$ There is a high correlation between neo-natal mortality and fertility as a mother who has lost her baby is more likely to have another baby, analytically and empirically shown by Bhalotra and van Soest (2008) in the Indian context.

${ }^{13}$ The problem is partly alleviated by applying pseudo panel where age cohorts are introduced in the model. 
${ }^{14}$ We have also used 'wealth index' which is based on the data of different household assets, characteristics and access to infrastructure, and have obtained similar results.

${ }^{15}$ See, for example, Wooldridge (2002, Chapter 15) for the details of ordered logit model. The use of ordered probit model or Poisson regression model gives broadly similar results and thus we report only those of ordered logit model.

${ }^{16}$ It is not possible to calculate the share of teenagers who were married or have given birth in the total number of teenagers due to data constraints. However, the number of married couples in which a wife was a teenager (15-19 years) is much smaller than that of any other age groups.

17 In our earlier version (Imai and Sato, 2010), we estimated the same model using three rounds of National Sample Survey data in 1993, 1999 and 2005 and obtained broadly similar results by using a proxy for the fertility rate based on a number of children under 15 years old in a household. However, given the possible measurement error in this proxy, we have decided to present only the results based on NFHS.

${ }^{18}$ We expect that grandmothers' education at the village level has a positive effect on mother's literacy in the first stage of IV, but the coefficient estimate is negative and significant. This may be because in the village (or district/ state) where education was more widely available a generation ago, government has spent a larger budget on literacy projects and thus some reversal may have occurred.

${ }^{19}$ If the positive coefficient estimate of father's literacy in Case (E) is valid, we would conjecture that educated men tend to have a larger bargaining power and impose the traditional value of large family on women. This is contradictory to the results of Case (A) or (C).

${ }^{20}$ Note that we excluded Muslim households with more than one female spouse of a male household head.

${ }^{21}$ As the pseudo-panel model involves averaging mother's and father's education at state level, the average education of mothers and that of fathers are highly correlated. Inclusion of both mother and father education in the model has lead to the results which are counterintuitive and incoherent due to multicollinearity and it was not possible to insert both at the same time.

${ }^{22}$ The results are not reported but will be furnished on request. 